\title{
What Operational Characteristics of Mutual Funds Affect Exit Decisions and When? Evidence from Taiwan
}

\author{
Nan-Yu Wang ${ }^{1} \&$ Chih-Jen Huang ${ }^{2}$ \\ ${ }^{1}$ Department of Finance, Ta Hwa University of Science and Technology, Hsinchu, Taiwan \\ ${ }^{2}$ Department of Finance, Providence University, Taichung, Taiwan \\ Correspondence: Nan-Yu Wang, Department of Finance, Ta Hwa University of Science and Technology, 1, \\ Dahua Rd., Qionglin Shiang Hsinchu County, 30740 Taiwan. Tel: 866-3-592-7700 ext. 3102. E-mail: \\ nanyu@tust.edu.tw
}

Received: March 13, 2013

Accepted: March 28, 2013

Online Published: April 18, 2013

doi:10.5539/ijef.v5n5p104

URL: http://dx.doi.org/10.5539/ijef.v5n5p104

\begin{abstract}
We investigated fund operating characteristics that cause fund companies to perform fund exit decisions and at what point of funds' lifecycles apply to fund liquidation or mergers. We also examined whether extra variable causes an important determinant effect and how fund operating characteristics before and after fund liquidations or mergers change. The empirical results show that: (1) the factors that affect within-family mergers are fund performance and flow from both cross-section and time-series views. The total net assets affect within-family mergers just in a cross-section analysis, not a lifecycle characteristic in a time-series analysis. Moreover, we found that performance volatility also affects exit decisions. The expense ratio and fund age are not the determinants for three type fund exits in Taiwanese onshore funds. (2) For the liquidation, total net assets, flow, performance volatility, and mid-term buy-hold returns have a significantly negative relationship with the fund liquidations from both the cross-section and time-series views. (3) In general, cross-family fund mergers are potentially conducted for strategic considerations rather than based on specific factors. (4) The performance volatility level before and following mergers was substantial and significant for within-family fund mergers; the expense ratio level before mergers was significant greater than following mergers for cross-family fund mergers.
\end{abstract}

Keywords: fund liquidation, fund merger, fund flow, fund performance, logistic regression

\section{Introduction}

Mutual funds continue to be popular investment vehicles. In fact, according to Taiwan's Securities Investment Trust and Consulting Association, the total numbers of mutual funds increased from 157 in 1997 to 973 as of December 2010. Exit strategies among mutual funds are a relatively recent phenomenon, but given rapid growth in the fund industry, reducing excess funds is understandable. The U.S. Morningstar Investment Research Center indicated that fund mergers were once widely practiced in the U.S., causing many investors to encounter fund liquidations and mergers. Regarding funds in Taiwan, mergers have become increasingly widespread since the Securities and Futures Commission under the Ministry of Finance enacted the Guidelines for Mergers of Securities Investment Trust Funds on November 1, 2001. Wang and Chen (2009) found that by the end of 2007 , approximately $30 \%$ of funds had been liquidated or merged. In 2008 alone, unique phenomenon occurred in that 81 funds were liquidated or merged, outnumbering newly raised funds that year, which numbered 63. Given these circumstances, the exit decisions act as an important term in the mutual fund industry.

Previous studies have analyzed mutual fund exit decisions. Overall, they found that the different determinants for the different exit decisions. For mergers, fund families use within-family mergers to disguise the poor past performance of the target funds (Jayaraman et al., 2002; Allen and Parwada, 2006; Gruber and Blake, 1996); cross-family mergers are motivated by other strategic reasons (Jayaraman et al., 2002). Zhou and Chiang (2007) additionally sampled external fund acquisitions and found that mutual-fund acquisitions facilitated the separation of managers from the funds they manage. Cakici and Chatterjee (2007) indicated the characteristics of hedge fund mergers are underperformed, lower money-flow, larger and older funds. Other studies have focused on fund termination. The factors that contributed to U.S. mutual funds disappearing are performance, scales or expense ratios (Brown and Goetzmann, 1995; Bu and Lacey, 2009; Evans, 2004). Existing literature has focused on termination probabilities (Lunde et al., 1999; Cameron and Hall, 2003; Horst et al., 2001). Zhao (2005) 
discussed both liquidated and merged funds because fund families may consider alternative exit forms. Accordingly, our study aims to clarify the following three types of exit strategies within our samples: liquidation, within-family mergers, and cross-family mergers.

To analyze the determinants of mutual fund mergers and liquidation, previous research focused on cross-section analysis alone. For example, previous studies used logistic and multinomial logistic regression to report the factors of mergers (Jayaraman et al., 2002; Zhao, 2005), whereas Brown and Goetzmann (1995) studied which characteristics affected fund disappearance using the probit model. In the present paper, however, we not only want to identify more precisely what kinds of funds merge or liquidate, but also want to know "when" they choose to do so. The fund company could subsequently consider market penetration strategies and decide the types of funds and fund characteristics that could depend on the product's life cycle to merge or liquidate their funds (Muga and Santamaria, 2010). After a new fund is established, when do domestic investment trust companies decide to liquidate or merge? And, on what characteristics during a fund's lifecycle do they make this decision? Cooper et al. (2005) discussed at what point in the life cycle the funds choose to change their names. Ahmad and Kashian (2010) also used the time series dimension to discuss the time varying covariates in their estimation to supply the lack of cross-sectional observations. Thus, examining the time-series views for each merger or liquidation fund is essential to the joint study of the full spectrum of revealing the factors that influence exits.

Most of the existing literature on what determines fund mergers or liquidations aims to clarify performance, asset flows, fund size, expense, ratio, and so on. Furthermore, the direct influence of the determinant causes exit decisions. What distinguishes the present study from previous studies is that in addition to fund characteristics, we also consider performance volatility as a determinate for the cross-section and time-series views. This issues been addressed in previous studies on fund liquidations and mergers. Huang et al. (2012) mentioned that performance volatility is an important factor of a fund's operating characteristics for investor learning and mutual fund flow. Brown et al. (1992) verified the tendency for one fund to persist in outperforming another if its volatility was higher. In other words, when the performance volatility was lower, the poorer the fund performed. In particular, fund performance is very susceptible in Taiwan, because the development time of the mutual fund industry is relatively short. Hence, we conjecture that the volatility of returns may play an important explanatory role of fund mergers and liquidation and may have negative effects on fund exits.

The present study investigated the relationship between fund liquidations/mergers and fund operating characteristics by using data published by the Taiwan Economic Journal (TEJ) from January 1, 2001 to December 31, 2010. According to data regarding the status of fund liquidations and mergers in the database, 170 onshore funds had been liquidated, and 155 had been merged (i.e., dissolved funds) into surviving funds by December 31, 2010. From both the cross-sectional and longitudinal views, the empirical results indicate as following. First, within-family mergers (exits that may take the form of a liquidation or a merger with another portfolio within the same fund family) tended to eliminate funds that had small total assets, low flows, and poor performance. In addition, the mean flows of the acquiring and acquired funds during six-months period before the merger were lower compared with their flows at other points in the lifecycles. Second, one year following cross-family mergers (liquidation or a merger with another portfolio within a different fund family), flows increased and operating costs decreased. However, the expense ratio charged to the shareholders of the dissolved funds increased, whereas the expense ratio charge to the original shareholders of the surviving funds decreased. The quality of returns that investors gained following mergers was uncertain and performance volatility was greater than before. In general, fund companies' considerations for liquidations and mergers were strategic rather than specific factors. Third, the factors that influenced onshore fund liquidations in Taiwan were small-scale, low, short-term flows, poor short-term performance, low performance volatility, poor medium-term (i.e., six months) buy-and-hold returns, and poor long-term performance. The total assets in the month preceding the month of the merger, the performance volatility during the past 12 months, mean flows during the past six months, and the buy-and-hold returns for the past six months were all lower compared with those at other points in the fund's lifecycle.

To summarize, the present research contributes to the literature at minimum in the following ways. First, it differs from the aforementioned studies in using a broader view to analyze three types of exit strategies of Taiwanese onshore funds that underwent liquidation or mergers. Second, we used relatively complete analysis (multinomial and time-series logistic regression analysis) to discuss the operating characteristics of funds that merge or liquidate and when (in other words, what characteristics of the fund lifecycle cause investment trust companies to perform fund liquidations or mergers). We show cross-section and times-serices views to provide richer information. Third, in addition to the common present variables discussed for mutual fund mergers and 
liquidations, the present study tests whether performance volatility also causes an important determinant effect. Fourth, previous domestic or international studies have focused primarily on issues such as fund performance, fund manager salaries, fund development, and fund management and governance, whereas few studies have been conducted to analyze fund liquidations and mergers. The present study compensates for the dearth on these aspects of the fund industry. Moreover, this is the first study to use cross-sectional and longitudinal analysis to examine fund characteristics, which seldom address fund liquidations and mergers. Finally, fund companies frequently tell their shareholders that mergers can increase the economies of scale for single fund management, adjust the flexibilities of operating strategies, reduce fund-related charges and operating costs, and "can" enhance fund business benefits by considering investors' best interests. Can investment trust companies achieve the expected benefits that they promise to fund beneficiaries as reasons for mergers? The present study explores the influences that the exit strategies of Taiwanese onshore funds have on the changes in fund's characteristics. The results can serve as references for investors in formulating investment strategies.

The remainder of this paper is organized as follows. Section 2 constitutes a literature review of relevant domestic and international studies. Section 3 comprises the study's hypotheses, the research scope, and methods used in the analysis. Section 4 explains the basic descriptive statistics for the data and discussions the empirical results. Section 5 provides a conclusion and discussion for future studies.

\section{Types of Fund Exit Strategies and Testable Hypotheses}

The present study sampled three types of Taiwanese onshore funds that underwent liquidation or mergers: (1) funds that were merged across families, (2) funds that were merged within families, and (3) liquidated funds. First, a within-family merger fund involves combining two funds within the same fund family. In Taiwan, the majority of within-family mergers were bond and stock fund mergers. Bond funds might have been targeted because a competent authority ruled that bond funds must be transformed or distributed, or investment trust considerations were influenced by increased global interest rates. Stock fund mergers may have occurred because global stock markets performed poorly in the years leading up to 2008, and the Taiwanese stock market was affected by various factors. In contrast, a merger can occur across two different fund families. An example of cross-family funds is managing four funds changed from the Industrial Bank of Taiwan Investment Trust Co. (a dissolved company) to the Taishin Securities Investment Trust Co., Ltd. (a surviving company). Cross-family fund mergers might not depend only on its own cross-section attributes, but may consider the time-series of lifecycle development of fund families. The product life cycle and portfolio matrix can be combined to provide a more comprehensive framework for strategic analysis (Barksdale and Harris, 1982). Thus, we are interested in at what point in their lifecycle funds choose to merger to another family. Another exit form is liquidation, when fund scales are small, because this can significantly reduce the stock selling pressure that results from fund liquidations. In Taiwan, fund liquidations actually outnumbered mergers during the past decade. Among various fund exit strategies, the market prefers fund companies that perform mergers rather than liquidations. This is because investment trust companies should enhance the quality of their operations during early fundraising or the subsequent management processes to prevent their funds from being closed. Otherwise, fund companies do not have to pay for their mistakes, and investors must continually suffer losses. So, to consider liquidations as the present study's scope is essential.

The existing literature on fund exits has noted that several hypotheses regarding mergers and liquidations, such as the effect of fund size, inflows, performance, and expense ratios are drawn directly from Jayaraman et al. (2002) and $\mathrm{Bu}$ and Lacey (2009). We introduce these and other relevant motives for fund exit mechanisms within this section.

\subsection{Fund Performance}

One potential motivation for fund mergers and liquidations is that the original fund has performed poorly. In mergers, surviving funds maintain superior performance when they are merged with dissolved funds that have poor performance (Elton et al., 1996). Fund companies can use within-family mergers to hide the previous poor performance of the dissolved fund (Jayaraman et al., 2002). Regarding fund liquidation, the termination probabilities of U.K. funds were negatively correlated with fund returns (Lunde et al., 1999). Previous quarterly returns affected fund disappearance in U.S. mutual funds (Horst et al., 2001). Funds with high returns were less likely to be terminated (Cameron and Hall, 2003). Liquidation can occur after poor performance and or for random reasons (Vayanos, 2004). When a fund family member is performing poorly, it may also likely to be sold to other fund families to reduce the relevant costs spent on research projects and marketing. Thus, we hypothesize that the motives for undertaking a within-family fund merger may differ from those for an across family merger. To eliminate the poor performance of dissolved funds, the performance would be a significant 
motivation for a within-family merger and a liquidation fund. Moreover, we also hypothesize that the performance was less compared with those at other points of the lifecycles.

\subsection{Fund Flows}

One of the common explanations provided for fund exits is the desire to fund flows. Fund flows can rationally reflect previous performance (Berk and Green, 2004). The fund flows and performance characteristics of Greek bond funds impacted returns (Dritsakis et al., 2006). During fund closure periods, these funds had superior performance and flows (Bris et al., 2007). Kempf and Ruenzi (2008) examined the effects that a fund's position within a fund family had on subsequent net inflows. Allen and Parwada (2006) used cross-sectional regression to examine investors' responses to the mergers of Australian fund companies and the influences of excess capital inflows and outflows in open-ended mutual fund. Significantly lower capital flows before merging were more likely to be merged (Cakici and Chatterjee, 2007). The net asset flows of the dissolved funds were lower compared with those of the acquiring funds (Khorana et al., 2007). Thus, if the fund flow is lower before the merger or liquidation, this may cause fewer economies of scale in the fund company. We hypothesize, therefore, that net asset flows may be significant in predicting the likelihood of the three forms of fund exits. It would be a significant motivation for a within-family merger and a liquidation fund. Moreover, we also hypothesize that the flows were less compared with those at other points of the lifecycles.

\subsection{Fund Size}

The motivation for fund exits may differ based on fund size. Much of the existing academic research on fund size has focused on fund mergers and liquidations. Funds that have larger scales, for example, are less likely to be terminated (Brown and Goetzmann, 1995). Regardless of whether the mergers were within-family or cross-family, all mergers negatively correlated with fund scale (Jayaraman et al., 2002). The investment portfolios of all dissolved funds had relatively small scales and few capital inflows; only funds that had the smallest scale (i.e., small market shares or rates) (Zhao, 2005). In Taiwan, on average, if the fund size is too small (average size is lower than 300 million dollars), the fund company would consider the operation costs to be inefficient and would merge funds with the same category of funds. But, if the fund could not maintain or has difficulty on resale, the fund company would likely start to consider liquidating the single fund. In our analysis, we hypothesize, therefore, that fund size is a determinant for a within-family merger and a liquidation fund. Moreover, we also hypothesize that the total net assets were not difference compared with those at other points of the lifecycles because the fund size has no large change in the short time.

\subsection{Expense Ratios}

Fund companies frequently declare that mergers can increase the economies of scale for managing single funds, reduce fund-related charges, and reduce operating costs by considering investors' best interests. Funds that have higher expense ratios increase the likelihood that a fund will be terminated (Brown and Goetzmann, 1995). The expense ratios of dissolved funds were higher compared with those of general funds. In contrast, the fees of the surviving funds were higher compared with those of matching funds and the dissolved funds (Elton et al., 1996). The expense ratios of these funds decreased, whereas the performance of the acquiring or surviving funds deteriorated significantly following mergers (Jayaraman et al., 2002). For the shareholders of dissolved funds, fees following mergers significantly decreased, whereas the fees of the acquiring funds did not (Khorana et al., 2007). In Taiwan, the expense ratios may not affect the merger of funds because the acquiring and acquired fund's expense ratios are similar and the different is small. We would expect, therefore, to observer no effects on mergers or liquidations.

\subsection{Performance Volatility}

The existing literature suggests that performance volatility is also an important factor for mutual fund industry. For example, Bekaert and Harvey (2002) believed that the volatility of capital flows became larger and larger by provoking capital market liberalization; thus, they discussed the volatility effect in their research. The literature therefore studied that the moving capital and volatility of fund flows also gradually increased. For example, Huang et al. (2007) and Ping (2001) investigated the effects and relationship between performance and fund flows for the actively managed mutual funds. Huang et al. (2012) illustrated theoretically that when some sophisticated investors learn from past fund performance to form their posterior expectations of managerial ability, the flow-performance sensitivity should be weaker for funds with more volatile past performance and longer track records. Cameron and Anthony (2003) also discussed the survival analysis of Australian equity mutual funds using the volatility of fund performance. Massa and Patgiri (2009) found that the probability of a fund's survival relates positively to the volatility of the fund return. Hence, we hypothesize the volatility of fund performance as a determinant and an effect on fund exits. Moreover, we also hypothesize that the performance 
volatility was a determinant compared with those at other points of the lifecycles.

\subsection{Fund Age}

Previous studies have documented the relationship between fund age and fund exits. For example, Brown and Goetzmann (1995) showed that younger funds that are more likely to be terminated or dissolved. Lunde et al. (1999) found that both young and extremely old funds were those most likely to be closed, whereas funds that had superior track records were less likely to be closed. Horst et al. (2001) found that previous quarterly returns and fund ages affected fund disappearance. Zhao (2005) found that newly established funds were likely to be liquidated. Considering that old funds with longer histories can increase market share, fund companies prefer to merge funds that are within the same families rather than liquidating funds. Cakici and Chatterjee (2007) found that the majority of merged funds in their sample were old funds. Therefore, fund age may be significant in predicting the likelihood of a fund exit in Taiwan.

\section{Research Method}

In the present study, we investigate (1) what fund operating characteristics and when are likely to cause fund companies to apply for fund liquidations or mergers, and (2) the effects on flows and subsequent returns for surviving and dissolved funds before and following mergers.

\subsection{Multinomial and Time-Series Logistic Regressions}

In the broad sense, linear models use logistic link functions, which are primarily employed in situations in which the response variables are binary data, such as "success" or "failure." In addition, $\mu$ is between 0 and 1 (Agresti, 1996). The model, therefore, was:

$$
\log \left(\frac{\mu}{1-\mu}\right)=\alpha+\beta_{1} x_{1}+\ldots+\beta_{m} x_{m}
$$

Cox (1970) proposed that from a mathematics perspective, logistic regression is an extremely flexible and easy-to-use function that can be employed to solve problems involving categorical data. This type of analysis is adopted mainly to identify the response variables of the categorical data and to explore the relationships among a series of explanatory variables.

To elucidate the relationships between the characteristics of merged funds and unmerged funds, we assumed that the dummy variable was 1 for fund mergers and 0 for unmerged funds, and set the response variable as $\pi(x)=p(y=1 \mid x)$, where $\pi(x)$ was a parameter of the Bernoulli distribution. Therefore, the logistic model for the univariates was:

$$
\begin{gathered}
\log i t \quad[\pi(x)]=\log \left[\frac{\pi(x)}{1-\pi(x)}\right] \\
E[y \mid x]=\pi(x)=\frac{\exp \left(\beta_{0}+\beta_{1} x\right)}{1+\exp \left(\beta_{0}+\beta_{1} x\right)}
\end{gathered}
$$

Johnsen and Melicher (1994) compared the predictive abilities or power of logit models and multinomial logit models (MNLM), as well as type I and II errors in both models, which can be used as evaluation criteria for model prediction accuracy. The empirical results showed that the performance of the MNLM was superior to that of the logit model. Regarding the use of estimation methods, because MNLM are non-linear models, we used the maximum likelihood estimation method to estimate the parameters. We attempted to use numerical methods to obtain the estimated value that could maximize the likelihood function. The logarithmic likelihood function was $\operatorname{lnL}=\sum_{i=1}^{N} \sum_{j=1}^{J} d_{i j} \ln P_{i j}$, where $i$ was the number of samples, $j$ represented a fund category, $\mathrm{P}_{i j}$ was the likelihood of Fund $i$ appearing in Category $j$, and $\mathrm{d}_{i j}$ was a set of dummy variables. If $Y_{i}=j, d_{i j}=1$.

In addition, McFadden (1973) indicated that using MNLM must satisfy the independence of the irrelevant alternatives (IIA), meaning that the opportunity ratio of the two alternatives should be irrelevant to the probabilities of the other alternatives. In other words, the probability ratio of the two categories in the explained variables should not be influenced by other categories. We used the Hausman test proposed by Hausman and McFadden (1984) for independence verifications. The Hausman-Mcfadden test assumes that because the opportunity ratio of the two alternatives is not influenced by or correlated to a certain alternative category, removing this category from the samples should not cause systematic changes to the estimated values of the parameters. Furthermore, the parameter estimated values of these alternative categories should be consistent. However, if the removed alternative categories are not truly independent of the remaining categories, the 
parameter estimated values obtained after removing certain alternative categories becomes inconsistent. The test statistics are $H_{I I A}=\left(\hat{\beta}_{R}-\hat{\beta}_{F}^{*}\right)\left[\operatorname{Var}\left(\hat{\beta}_{R}\right)-\hat{\operatorname{Var}}\left(\hat{\beta}_{F}^{*}\right)\right]^{-1}\left(\hat{\beta}_{R}-\beta_{F}^{*}\right)$, where the values approach the $\chi^{2}$ distribution and the degree of freedom is the number of series or columns in $\hat{\beta}_{R}$. If the test statistics are greater than the critical value, the IIA assumption does not hold.

We divided the fund exit strategies into three categories - liquidation, within-family mergers, and cross-family mergers - to explore the objective determinants of fund liquidations and mergers in Taiwan. We investigated the fund operating characteristics that caused fund companies to perform fund mergers and at what point in the funds' lifecycles the fund companies applied for fund liquidation or mergers. We conducted cross-sectional multiple and time-series logistic regression analyses on the overall funds. In the cross-sectional multiple logistic regression analysis, we used fund operating characteristics as the explanatory variables. These included previous returns, previous total assets, previous flows, expense ratio, the buy-and-hold returns during the past six months, the annualized standard deviations during the past 12 months, the average flows during the past six months, Jensen's $\alpha$ during the past 12 months, and years of establishment. For the regression analyses, we defined the dummy variable of the liquidated/merged funds as 1 and that of non-liquidated/unmerged funds as 0 .

In the time-series logistic regression analysis, we used various fund operating characteristics (i.e., previous total net value, the buy-and-hold returns during the past six months, the annualized standard deviations during the past 12 months, the average flows during the past six months, Jensen's $\alpha$ during the past 24 months, and the buy-and-hold returns of the corresponding matching funds during the past six months) as the explanatory variable combinations for merged funds (i.e., surviving funds). The corresponding matching funds all had the same investment objects. We employed time-series logistic regression to analyze the liquidated or merged funds using all of the funds' available or applicable lifecycle data as the time-series data. We defined the value of the month during which the fund liquidation or merger was performed as 1 and the lifecycle of the remaining months as 0 .

\subsection{Sample Descriptions}

We sampled all Taiwanese funds that were liquidated and merged to examine the degree to which fund companies achieved the benefits they promised beneficiaries when announcing the merger (i.e., claims that mergers would improve overall fund performances). We used data published by the TEJ from January 1, 2001 to December 31, 2010 and extracted the attributes of Taiwanese funds. According to data regarding fund liquidations and mergers in the database, 170 funds were liquidated and 155 were merged (i.e., dissolved) into surviving funds by December 31, 2010.

The names of the dissolved funds were changed following the mergers, although the fund types remained the same. We examined changes to the number of funds that Taiwanese fund management companies managed before and following liquidations or mergers. We found that only 10 funds were managed by a different management company following mergers. The remaining sampled funds were within-family mergers. For the following fund management companies, $100 \%$ of the funds they managed were liquidated: Ta Chong Bank; JihSun International Commercial Bank Co., Ltd.; Fubon Financial; Bank SinoPac; and Bowa Successful Management Co., Ltd. For the following fund management companies, less than $10 \%$ of the funds they managed were liquidated or merged: Taishin International Bank Co., Ltd.; Fuh Hwa Securities Investment Trust Co., Ltd.; JPMorgan Asset Management; and Prudential. Thirty-three securities fund companies had more than 30\% of their funds liquidated or merged, which accounted for $70 \%$ of the 47 fund companies in Taiwan.

We used TEJ fund-ranking database, fund fee and bond fund income database, and fund turnover rate database to collect the variables of the fund performances and various fund operating characteristics. The variables included returns, total net value, flows, expense ratio, performance volatility levels, and performance indicators, which comprise the original rate of return, Jensen's $\alpha$, the Sharpe index, and information ratio. We adopted monthly data from these databases and compared the empirical results of within-family and cross-family mergers.

Table 1 includes the descriptive statistics of the within-family and cross-family mergers and categories of the investment targets of Taiwanese funds. As of December 31, 2010, the majority of these mergers were within-family mergers (145 of 155 , accounting for $93.55 \%$ of the total mergers), whereas cross-family mergers were rare (10 of 155 , accounting for $6.45 \%$ of the total mergers). Regarding the types of investment targets following mergers, the majority were equity funds $(52+4=56$, which was 56 of the 155 , accounting for $36.13 \%$ of the total mergers), followed by bond funds (35 of 155, accounting for $22.58 \%$ ), and then stock and bond balanced funds (30 of 155, accounting for 19.36\%). 
Table 1. Descriptive statistics of the within-family and cross-family mergers and categories of the investment targets of Taiwanese funds

\begin{tabular}{|c|c|c|c|c|c|c|c|c|c|c|c|c|c|c|c|c|}
\hline \multirow{3}{*}{ Year } & \multicolumn{11}{|c|}{ Within / Cross family mergers } & \multicolumn{5}{|c|}{ Liquidations } \\
\hline & \multicolumn{2}{|l|}{ Stock } & \multicolumn{2}{|c|}{ Balanced funds } & \multicolumn{2}{|l|}{ Bond } & \multicolumn{2}{|l|}{ Others } & \multicolumn{2}{|l|}{ Total } & \multirow[t]{2}{*}{ Total } & \multirow[t]{2}{*}{ Equity } & \multirow[t]{2}{*}{ Balanced funds } & \multirow[t]{2}{*}{ Bond } & \multirow[t]{2}{*}{ Others } & \multirow[t]{2}{*}{ Total } \\
\hline & Within & Cross & Within & Cross & Within & Cross & Within & Cross & Within & Cross & & & & & & \\
\hline 2001 & 1 & 0 & 0 & 0 & 0 & 0 & 1 & 1 & 2 & 1 & 3 & 8 & 0 & 0 & 1 & 9 \\
\hline 2002 & 11 & 0 & 0 & 0 & 1 & 0 & 4 & 0 & 16 & 0 & 16 & 1 & 0 & 0 & 1 & 2 \\
\hline 2003 & 4 & 0 & 1 & 0 & 0 & 0 & 1 & 0 & 6 & 0 & 6 & 2 & 0 & 0 & 1 & 3 \\
\hline 2004 & 2 & 0 & 1 & 0 & 1 & 0 & 1 & 0 & 5 & 0 & 5 & 3 & 0 & 1 & 3 & 7 \\
\hline 2005 & 5 & 3 & 2 & 0 & 0 & 0 & 1 & 1 & 8 & 4 & 12 & 4 & 1 & 7 & 2 & 14 \\
\hline 2006 & 2 & 0 & 9 & 1 & 12 & 0 & 4 & 0 & 27 & 1 & 28 & 4 & 9 & 7 & 10 & 30 \\
\hline 2007 & 5 & 1 & 7 & 0 & 13 & 0 & 1 & 0 & 26 & 1 & 27 & 4 & 4 & 10 & 8 & 26 \\
\hline 2008 & 15 & 0 & 4 & 0 & 6 & 1 & 7 & 1 & 32 & 2 & 34 & 11 & 15 & 2 & 19 & 47 \\
\hline 2009 & 4 & 0 & 1 & 0 & 0 & 1 & 4 & 0 & 9 & 1 & 10 & 3 & 3 & 0 & 1 & 7 \\
\hline 2010 & 3 & 0 & 8 & 0 & 0 & 0 & 3 & 0 & 14 & 0 & 14 & 2 & 5 & 2 & 4 & 13 \\
\hline Total & 52 & 4 & 33 & 1 & 33 & 2 & 27 & 3 & 145 & 10 & 155 & 52 & 37 & 30 & 51 & 170 \\
\hline
\end{tabular}

Description: This study samples fund attributes from the TEJ data that were published or available before December 31, 2010. After reviewing fund liquidations and within-family or cross-family mergers over the years, we obtained 155 merged funds and 170 liquidated funds based on the number of funds that had different types of investment targets before mergers. These statistics were obtained from January 1, 2001 to December 31, 2010.

Ten Taiwanese stock and bond balanced funds were merged in 2006. This was possibly because (1) companies that managed this type of fund converted their outright bond purchasing and selling transactions for cash assets into actual bond holdings; (2) when the fund scales reached NT\$200 million, government bonds accounted for $25 \%$; and (3) the corporate bond market was not active during 2006. Therefore, managers of other types of funds could not manage these funds. Although the scales of these funds are small, they required specialized managers. Consequently, these funds were likely to be merged when considering the benefits.

The majority of mergers between 2006 and 2007 were bond fund mergers, totaling 25 cases. This was the case because (1) the competent authority ruled that bond funds must be transformed or distributed or (2) investment trust considerations were influenced by increased global interest rates, causing investors to gradually abandon conservative investment strategies. Consequently, fund scales decreased. Therefore, fund companies decided to merge their funds to reduce selling pressure resulting from fund realization. The majority of mergers in 2008 were equity fund mergers, and 47 funds were liquidated. This may have been the case because global stock markets performed poorly in the years leading up to 2008, and the Taiwanese stock market was affected by other factors. In this year alone, 15 funds were merged and 11 were liquidated. Many equity funds were merged under the influence of a bear market. Furthermore, the majority of the balanced funds involved outright bond purchasing and sales transactions of cash assets, which must be transformed into actual bond holdings within a given time frame. Although fund companies were granted a buffer period, they decided to liquidate or merge balanced funds after considering the benefits. This was possibly the case because the market was inactive and these funds could not be managed by managers that had been managing other types of funds.

\section{Empirical Results}

\subsection{Descriptive Statistics}

To examine the relationship between Taiwanese fund liquidations and mergers and fund characteristics, we first summarized the descriptive statistics of the operating characteristics of the overall liquidated and merged funds and unmerged funds, including previous returns, previous total assets, previous flows, expense ratio, buy-and-hold returns during the past six months, annualized standard deviations during the past 12 months, average flows during the past six months, and Jensen's $\alpha$ during the past 12 months. We compared the statistics of the liquidated and merged funds with those of funds that were not liquidated or merged.

Table 2 includes the means of the fund characteristics for the liquidated funds, within-family and cross-family mergers, and other non-liquidated or unmerged funds. We used statistics for the months when the liquidations or mergers occurred as the basis for fund matching. The fund characteristics consisted of the total assets in the month preceding the liquidation or merger; performances (i.e., in the preceding month, during the last six months preceding the liquidation or merger, returns during the first six months of holdings, and Jensen's $\alpha$ during the past 24 months); flows (i.e., in the preceding month and the preceding six months); measurement indices for cost 
structures; and the annualized standard deviation of the returns. We obtained the annualized standard deviations based on the monthly rate of return in the past 12 months, without calculating the statistics of the funds that were founded less than 12 months prior. The equation was $\sigma_{i} * \sqrt{12}$. In particular, the performance measurement indices comprised Jensen's $\alpha$, the Sharpe index, and the information ratio. The measurement indices for the cost structures consisted of expense ratios (i.e., manager fees, custodial fees, guarantee fees, and other fees). Finally, $r_{t}$ is the fluctuation range of the unit net values in the last month during Term $t$.

The data in Table 2 shows that in within-family and cross-family mergers, the performance measurement indices of the dissolved funds before mergers, except for the Sharpe index, were all inferior compared to those of the surviving funds. When the asset scales of the funds are small, fund companies might not be able to pay or cope with fixed costs and thus fail to make a profit. Therefore, fund companies are likely to liquidate these funds. Fund performances during the six months preceding liquidation or elimination were primarily negative, and the returns of these funds tended to be lower compared with those of the funds that were not liquidated or merged. The performance volatility of the liquidated or merged funds was inferior compared with that of the funds that were not liquidated or merged. More crucially, the fund flows during the six months preceding liquidation or merger were primarily negative and lower compared to the fund flows of the funds that were not liquidated or merged. Furthermore, the fund flows of the dissolved funds prior to mergers were inferior compared with those of the surviving funds. Examining the cost structures showed that in the within-family mergers, the expense ratios of the previous month for the dissolved funds all exceeded those of the surviving funds (Elton et al., 1996). Therefore, funds with high cost or expense ratios are likely to be within-family mergers.

Table 2. The descriptive statistics of the liquidated and merged funds compared with all funds

\begin{tabular}{|c|c|c|c|c|c|c|}
\hline \multirow[t]{2}{*}{ Fund operation characteristics } & \multicolumn{2}{|c|}{ Within-family mergers } & \multicolumn{2}{|c|}{ Cross-family mergers } & \multirow[t]{2}{*}{ Liquidations } & \multirow[t]{2}{*}{ Others } \\
\hline & Surviving & Dissolved & Surviving & Dissolved & & \\
\hline Fund one month lagged total net assets & 4526.090 & 1855.826 & 2581.100 & 1476.400 & 252.103 & 4826.344 \\
\hline Fund one month lagged Jensen index & -0.043 & -0.440 & -0.065 & -0.295 & -0.530 & 0.084 \\
\hline Fund one month lagged Sharp index & -1.823 & -1.877 & -0.786 & -0.547 & -0.322 & -0.426 \\
\hline Fund one month lagged information ratio & 0.036 & -0.123 & -0.089 & -0.212 & -0.156 & 0.022 \\
\hline Fund one month lagged flow & -0.024 & -0.101 & 0.040 & -0.111 & -0.473 & -0.004 \\
\hline Fund one month lagged expense ratio & 0.113 & 0.118 & 0.126 & 0.119 & 1.059 & 0.124 \\
\hline Jensen index over past 6 months & -0.079 & -0.390 & -0.216 & -0.394 & -0.379 & 0.094 \\
\hline Sharp index over past 6 months & -1.808 & -1.693 & -1.289 & -1.153 & -0.252 & -0.405 \\
\hline Information ratio over past 6 months & 0.029 & -0.103 & 0.006 & -0.117 & -0.137 & 0.023 \\
\hline Fund buy-hold returns over past 6 months & -0.014 & -0.048 & 0.003 & -0.032 & -0.083 & 0.030 \\
\hline Stand deviation of fund returns over past 12 months & 15.174 & 14.640 & 14.842 & 16.244 & 11.948 & 16.719 \\
\hline Mean fund flow over past 6 months & -0.029 & -0.060 & 0.002 & -0.049 & -0.132 & -0.004 \\
\hline Jensen alpha calculated over past 24 months & -0.011 & -0.259 & 0.134 & -0.392 & -0.255 & 0.096 \\
\hline
\end{tabular}

Description: This table shows the sample characteristics of the liquidated and merged funds compared with other funds that were not liquidated or merged. These characteristics included the mean operation characteristics, the matching of which was based on the month of liquidation and merger. The operation characteristics comprised the total asset in the previous month (i.e., the fund's total asset values at the end of each month, measured in millions of NT dollars), performance (i.e., original rates of return, Jensen's $\alpha$, the Sharpe index, and information ratio), fund flow ([we used the equation proposed by Sirri and Tufano (1998), i.e., $\left[T N A_{t}-\left(1+r_{t}\right) T N A_{t-1}\right] / T N A_{t-1}$, measurement indices for cost structures (expense ratios), and annualized standard deviation (which we obtained based on the monthly rate of return in the past 12 months without calculating the statistics of funds that were established less than 12 months before).

\subsection{Multinomial Logit Model}

Considering the factors influencing differences in fund liquidation and merger methods, we used the multinomial logit model to establish an empirical framework to explore the fund characteristics that are likely to cause fund companies to liquidate or merge their funds. The fund family can dispose of funds in one of four ways: (1) a within-family mutual fund merger; (2) a without-family mutual fund merger; (3) liquidate the fund; (4) keep the fund in the family. The regression variables included the fund's one-month lagged total net assets, the fund's one-month lagged Jensen index, the fund's one-month lagged Sharp index, the fund's one-month lagged information ratio, the fund's one-month lagged flow, mean fund flow over the past six months, standard deviation of the fund's returns over the past 12 months, the fund's one-month lagged expense ratio, the fund's buy-hold returns over the past six months, Jensen $\alpha$ calculated over the past 24 months, and fund age.

To depict the linear relations between explanatory variables, we calculated the simple correlation coefficients. We computed the variance inflation factor (VIF) and conditional index to diagnose whether collinearity existed 
between variables (See Table 3). If the VIF is greater than 10 or the conditional index is greater than 15, then multicollinearity exists. The results show no evidence of multicollinearity. To get the multionomial logit model, we first tested the assumption of the independence of irrelevant alternatives, which states that the relative probabilities of two options being chosen are unaffected by removing the other alternatives.

Table 3. Collinearity diagnostics

\begin{tabular}{lll}
\hline Variables & VIF & Conditional index \\
\hline fund one month lagged total net assets & 2.637 & 2.165 \\
fund one month lagged raw return & 2.769 & 2.234 \\
fund one month lagged flow & 1.376 & 2.557 \\
mean fund flow over past 6 months & 2.114 & 2.727 \\
stand deviation of fund returns over past twelve months & 1.866 & 3.129 \\
fund one month lagged direct transaction costs rate & 1.464 & 3.824 \\
fund one month lagged expense ratio & 1.696 & 4.448 \\
fund one month lagged cost ratio & 1.294 & 4.984 \\
fund buy-hold returns over past 6 months & 1.328 & 5.858 \\
Jensen alpha calculated over past 24 months & 1.163 & 8.292 \\
fund age & 1.318 & 10.602 \\
\hline
\end{tabular}

Description:This table reports the variance inflation factor (VIF) and Conditional index to diagnose whether there are collinear between variables. If $\mathrm{VIF}>10$ or conditional index $>15$, the multicollinearity exists.

We also contend the test of independence of irrelevant alternatives (IIA) property cannot be rejected at the $1 \%$ significant level (See Table 4). Therefore, the multinomial logit model is an appropriate model for estimating this data. As such, we investigated the fund exit determinants using the MNLM. We considered three models, each with different fund performance. Table 5 shows the results of the cross-sectional multinomial logit model. The total assets in the previous month, mean flow, Sharpe index, and performance in the last 24 months in the within-family mergers tended to be significantly negative. This indicates that in Taiwanese fund mergers, fund companies are likely to merge a particular fund with other funds in the same family when the short-term fund flow (that is, in the previous month) is negative, and the long-term (that is, 24 months) fund performance is inferior compared with that of the surviving fund. Therefore, the characteristics that can cause within-family mergers in Taiwanese funds include small or low total assets, low short-term fund flow, and poor previous performance.

Table 4. Test of independence of irrelevant alternatives (IIA)

\begin{tabular}{llll}
\hline Alternative dropped & Chi-Square & Probability & evidence \\
\hline Liquidation & -9.716 & 1 & no reject H0 \\
Within-family merge & 3.896 & 1 & no reject H0 \\
With-out family merge & 0.984 & 1 & no reject H0 \\
keep the fund & -48.39 & 1 & no reject H0 \\
\hline
\end{tabular}

Description: This table reports the results for Hausman specification test with three of the alternative dropped. The result indicates that IIA property cannot be rejected at $1 \%$ significant level. Therefore, multinomial Logit model is an appropriate model for estimation of this data.

Table 5 presents that the total net assets, short-term performance, the fund's one-month lagged flow, and Jensen $\alpha$ calculated over the past 24 months have a significantly negative relationship with within-family merged funds. When fund performances are extremely poor, fund companies are likely to terminate the sales and merge the same family funds to dissolve funds with poor performances (Brown and Goetzmann, 1995; Elton et al., 1996; Jayaraman et al., 2002). However, previous low performance, total net assets and flow, cost structure, and performance volatility do not determine whether family companies conduct cross-family mergers. Instead, cross-family mergers are potentially conducted for other strategic motivations. When funds have small scales, low fund flow in the previous month, low performance volatility, and poor buy-hold return over the past six months and long-term performance, fund companies tend to liquidate these funds. Investors are not interested in investing in funds that perform poorly. Therefore, fund companies are likely to eliminate these funds through liquidation and within-family mergers to improve investors' overall impressions of the fund families. 
Table 5. Multinomial logit model estimates of merger and liquidation

\begin{tabular}{|c|c|c|c|c|c|c|c|c|c|}
\hline \multirow[t]{2}{*}{ Fund operation characteristics } & \multicolumn{3}{|c|}{ Within-family mergers } & \multicolumn{3}{|c|}{ Cross-family mergers } & \multicolumn{3}{|c|}{ Liquidations } \\
\hline & M1 & M2 & M3 & M1 & M2 & M3 & M1 & M2 & M3 \\
\hline Constant & $2.476^{* * *}$ & $4.214 * * *$ & $2.422 * * *$ & -0.271 & -0.853 & -0.700 & $3.91 * * *$ & $4.003 * * *$ & $3.996 * * *$ \\
\hline Fund one month lagged total net assets & $-0.943^{* * *}$ & $-1.639^{* * *}$ & $-0.889 * * *$ & -0.939 & -0.725 & -0.84 & $-1.87 * * *$ & $-1.885^{* * *}$ & $-1.858 * * *$ \\
\hline Fund one month lagged Jensen index & -0.398 & & & 0.219 & & & -0.441 & & \\
\hline Fund one month lagged Sharp index & & $-0.203 * * *$ & & & 0.152 & & & 0.060 & \\
\hline Fund one month lagged information ratio & & & -0.409 & & & -1.078 & & & -0.063 \\
\hline Fund one month lagged flow & $-3.388 * * *$ & $-2.646^{* *}$ & $-3.108 * * *$ & -4.719 & -5.134 & -4.663 & $-8.494 * * *$ & $-8.487 * * *$ & $-8.256^{* * *}$ \\
\hline Mean fund flow over past 6 months & -0.347 & 0.929 & -0.678 & 3.577 & 2.683 & 2.879 & 4.696 & 4.831 & 4.649 \\
\hline $\begin{array}{l}\text { Stand deviation of fund returns over past } \\
\text { twelve months }\end{array}$ & -0.024 & -0.017 & -0.023 & -0.023 & -0.022 & -0.018 & $-0.066^{* * *}$ & $-0.062 * * *$ & $-0.064 * * *$ \\
\hline Fund one month lagged expense ratio & -3.036 & -1.537 & -3.254 & -3.403 & -4.981 & -4.492 & -0.089 & -0.083 & -0.076 \\
\hline $\begin{array}{l}\text { Fund buy-hold returns over past } 6 \\
\text { months }\end{array}$ & 0.167 & -0.210 & -0.472 & 0.054 & 0.300 & 0.777 & -1.560 & $-2.473 * *$ & $-2.259^{* *}$ \\
\hline $\begin{array}{l}\text { Jensen alpha calculated over past } 24 \\
\text { months }\end{array}$ & -0.403 & $-0.646^{* *}$ & $-0.671 * *$ & -1.325 & $-1.152 * *$ & -0.903 & -0.458 & $-0.863 * *$ & $-0.851 * *$ \\
\hline Fund age & 0.04 & 0.011 & 0.034 & 0.05 & 0.073 & 0.063 & 0.011 & 0.006 & 0.002 \\
\hline
\end{tabular}

Description: A three-outcome multinomial logit model was used to investigate the distinction among different exit forms. The fund family can dispose funds by four choices: (1) a within-family mutual fund merge; (2) a cross-family mutual fund merge; (3) liquidate the fund; (4) keep the fund in the family. The variables included fund one month lagged total net assets, fund one month lagged Jensen index, fund one month lagged Sharp index, fund one month lagged information ratio, fund one month lagged flow, mean fund flow over past 6 months, stand deviation of fund returns over past twelve months, fund one month lagged expense ratio, fund buy-hold returns over past 6 months, Jensen alpha calculated over past 24 months, and fund age. $* * *$ and $* *$ indicate significant at the one and five percent, respectively. We use the three models with different explanation variables in merger/liquidation funds. M1: model 1; M2: model 2; M3: model 3.

In summary, performance is a significant motivation for a within-family merger and a liquidation fund in Taiwan. Poor short-term performance (Sharp index) and long-term performance (Jensen $\alpha$ ) are determinants on within family mergers. This conclusion is consistent with those proposed by Elton et al. (1996) and Jayaraman et al. (2002). On the other hand, poor short-term performance (Sharp index), mid-term performance (buy-hold returns), and long-term performance (Jensen $\alpha$ ) are determinants on liquidations. This conclusion is similar with those proposed by Lunde et al. (1999), Horst et al. (2001), and Vayanos (2004). Fund flows and fund size are significant in predicting the likelihood of the within-family merge and liquidation, but it is not a determinant and effect for a cross-family merge fund. Interestingly, the expense ratio is not a determinant for fund exits in Taiwanese onshore funds. These results differ from the previous literature in that the higher expense ratios increase the likelihood of terminating the fund (Brown and Goetzmann, 1995; Jayaraman et al., 2002; Zhao, 2005). This verifies that our pervious prediction is correct. The expense ratios do not affect the merger or liquidation of funds because the acquiring and acquired fund's expense ratios are similar and are not significantly different. Moreover, some scholars have argued that young and extremely old funds are the most likely to be closed (Lunde et al., 1999). This study found that fund age is also not a determining factor in Taiwanese fund mergers and liquidations. The result also differs from the previous literature (Brown and Goetzmann, 1995; Lunde et al., 1999; Horst et al., 2001; Zhao, 2005; Cakici and Chatterjee, 2007). These previous studies found that old or young funds intended to be merged or liquidated. It is worth mentioning that the volatility of fund performance is a determinant and effect on fund liquidation and had a significantly negative effect on fund liquidation for Taiwanese onshore funds. This result is similar with Massa and Patgiri's (2009) finding that the probability of a fund's survival relates positively to the volatility of fund return.

\subsection{Time-Series Logistic Regression Model}

Table 6 shows that the surviving funds in within-family mergers had significantly negative mean flows during the previous six months (with a coefficient of -6.791). This indicates that a fund company tend to merge a fund with other funds within its family when the surviving fund has a lower mean flow (in the prior six months) compared to other points in its lifecycle. Regarding the influencing factors for dissolved funds during within-family mergers, in addition to the effects of mean flow in the previous six months (with a coefficient of -4.747), funds that have poorer long-term performance (i.e., Jensen's $\alpha$ during the prior 24 months, with a coefficient of -0.430) compared to those at other points of the funds' lifecycles are likely to be merged with (dissolved by) other funds within the families. Furthermore, the lifecycle characteristics that are likely to result 
in fund liquidation of Taiwanese funds include small total assets in the previous month, low annualized standard deviation in the last 12 months, low mean flows in the previous six months, and lower buy-and-hold returns in the prior six months compared to other lifecycle points.

In summary, the factors that affect within-family mergers are fund performance and flow from both cross-section and time-series views. The total net assets affect within-family mergers just in a cross-section analysis, not a lifecycle characteristic in a time-series analysis. For the liquidation, total net assets, flow, performance volatility, and mid-term buy-hold returns have a significantly negative relationship with the fund liquidations from both the cross-section and time-series views. Poor long-term performance only affects the fund liquidation from a cross-section view, but it is not relevant for the lifecycle itself. Worth mentioning is that we also did not find any common fund operation characteristics such as a significant motivation for cross-family mergers, although we did observe them from the time-series view. In general, fund mergers between fund companies are possibly conducted for strategic considerations (e.g., changes in global capital markets or the need to lower the risks of single-market fund operations), rather than being based on specific factors (e.g., performance and flow).

Table 6. Determinants of fund liquidation and merger (results of the time-series logistic regression)

\begin{tabular}{|c|c|c|c|c|c|}
\hline \multirow[t]{2}{*}{ Fund operation characteristics } & \multicolumn{2}{|c|}{ Within-family mergers } & \multicolumn{2}{|c|}{ Cross-family mergers } & \multirow[t]{2}{*}{ Liquidations } \\
\hline & Surviving fund & Dissolved funds & Surviving fund & Dissolved funds & \\
\hline Constant & $-4.336 * * *$ & $-4.070 * * *$ & $-3.584 * * *$ & -1.454 & 0.237 \\
\hline Fund one month lagged total net assets & 0.000 & 0.000 & 0.000 & 0.000 & $-0.012 * * *$ \\
\hline Stand deviation of fund returns over past twelve months & 0.010 & 0.006 & -0.050 & -0.051 & $-0.051 * * *$ \\
\hline Mean fund flow over past 6 months & $-6.791 * * *$ & $-4.747 * *$ & 2.939 & 0.150 & $-4.384 * *$ \\
\hline Fund buy-hold returns over past 6 months & -0.960 & -1.425 & 1.733 & 0.245 & $-4.405 * * *$ \\
\hline Jensen alpha calculated over past 24 months & -0.104 & $-0.430 * * *$ & 0.257 & 0.037 & -0.281 \\
\hline Buy-hold return of corresponding style over the past 6 & -0.819 & -1.541 & -19.186 & -27.916 & -9.561 \\
\hline
\end{tabular}

months

Description: We examined the surviving funds and dissolved funds in within-family and cross-family mergers and liquidated funds to elucidate at what points of a fund's lifecycle and based on what characteristics fund companies perform fund liquidation or mergers. Table VII shows the results of the time-series logistic regression analysis of the fund characteristics. We used data from the two years preceding the month of the liquidation or merger to calculate Jensen's $\alpha$. We considered all of the usable lifecycle data of the liquidated or merged funds and defined the value of the month during which fund liquidation or merger was performed as 1 , and the lifecycle of the remaining months as 0 to calculate logistic regression analysis results. The explanatory variables comprised previous total assets, performances, flows, expense ratios, and buy-and-hold returns. The corresponding style funds are all of the same investment object funds. *** indicates that the $\alpha$ reached a level of significance at $1 \%$; ** indicates that the $\alpha$ reached a level of significance at $5 \%$.

\subsection{Changes in Fund Characteristics for Fund Liquidation or Mergers}

Using the average monthly changes in fund characteristics in the year before liquidation and merger and the year following liquidation and merger (Table 7), we explored short-term changes following mergers. The surviving funds in within-family and cross-family mergers both experienced increased fund flows following mergers. Allen and Parwada (2006) argued that rather than increasing fund flows, mergers cause investors to withdraw capital from the dissolved funds. However, we found no such phenomena. Nevertheless, the flows following the within-family mergers were negative, indicating that mergers cannot alter investors' net redemption tendencies. In contrast, the fund flows following cross-family mergers changed from negative $(-0.011)$ to positive $(0.015)$. The flows of the dissolved funds in within-family or cross-family mergers and the flows of the liquidated funds were all negative before the mergers. In addition, the flows of the dissolved funds were lower compared with those of the surviving funds.

In within-family and cross-family mergers, the total assets of surviving funds, flows, and performance volatility all increased, whereas expense ratios decreased (Kumar and Bansal, 2008). This indicates that mergers can increase fund management scales and reduce fees one year following a merger and verifies fund companies' claims to investors that mergers can reduce management costs. Increases in fund scales and flows following mergers indicate that mergers can reduce investors' regular purchases or redemption transactions and prevent significant asset management fluctuations or volatility. Fund performances varied depending on various performance measurement indices, and operational performances did not necessarily improve. This indicates that although fund companies expect to use mergers to reduce administrative costs and return a reasonable sum of costs to investors, they do not necessarily achieve these effects in later performance. The dissolved funds in within-family mergers all had negative performance, indicating that fund companies were likely to perform 
within-family mergers to erase records of poor performance for certain funds and hide unsuccessful records (Jayaraman et al., 2002; Zhao, 2005; Khorana et al., 2007). In contrast, cross-family merger factors were not meant to eliminate funds exhibiting poor performance. The performances of the liquidated funds before liquidation were all negative, which was similar to the result proposed by Brown and Goetzmann (1995). In other words, loser funds are more likely to be liquidated or merged, but not all loser funds are eliminated.

The performance of the surviving funds following mergers varied depending on the performance measurement indices. Performance following mergers did not necessarily improve, which is consistent with the assertions of Agrawal et al. (1992) and Khorana et al. (2007). These studies showed that following mergers, the assets or wealth of the shareholders of the surviving companies were reduced. The shareholders of the dissolved funds in within-family and cross-family mergers tended to benefit from the mergers. The surviving funds had superior performance compared with the dissolved funds following mergers potentially because the surviving funds had superior assets or their fund managers had superior operational skills compared with those of the dissolved funds. Khorana et al. (2007) confirmed that dissolved funds that performed poorly showed substantially improved performance following mergers and that this phenomenon was particularly evident in within-family mergers.

The flow of surviving funds prior to mergers was negative (-0.024), implying that fund companies may desire to eliminate the poor performance of dissolved funds to increase surviving funds and attract the investment of additional assets. The flow of surviving funds in within-family mergers increased from -0.024 to -0.003 following mergers. The fund flows following mergers were negative, indicating that investors were likely to redeem their money from the surviving funds following mergers. Furthermore, consistent with increases in fund flows, the total net assets also increased and showed significance, with the volatility level before and following mergers being substantial and significant. In contrast, the flow of surviving funds in cross-family mergers increased from -0.011 to 0.015 . The fund flow of surviving funds following mergers changed from negative to positive, indicating the increased flows of the surviving funds following cross-family mergers. However, fund performance did not necessarily improve, whereas volatility levels were more substantial and expense ratios decreased overall and were significant (Khorana et al., 2007). In general, cross-family fund mergers are potentially conducted for strategic considerations rather than based on specific factors. For example, Namvar and Phillips (2013) suggested that mutual fund mergers create collaborative benefits between funds with similar strategies.

Table 7. Changes in fund characteristics before and following fund liquidation or mergers

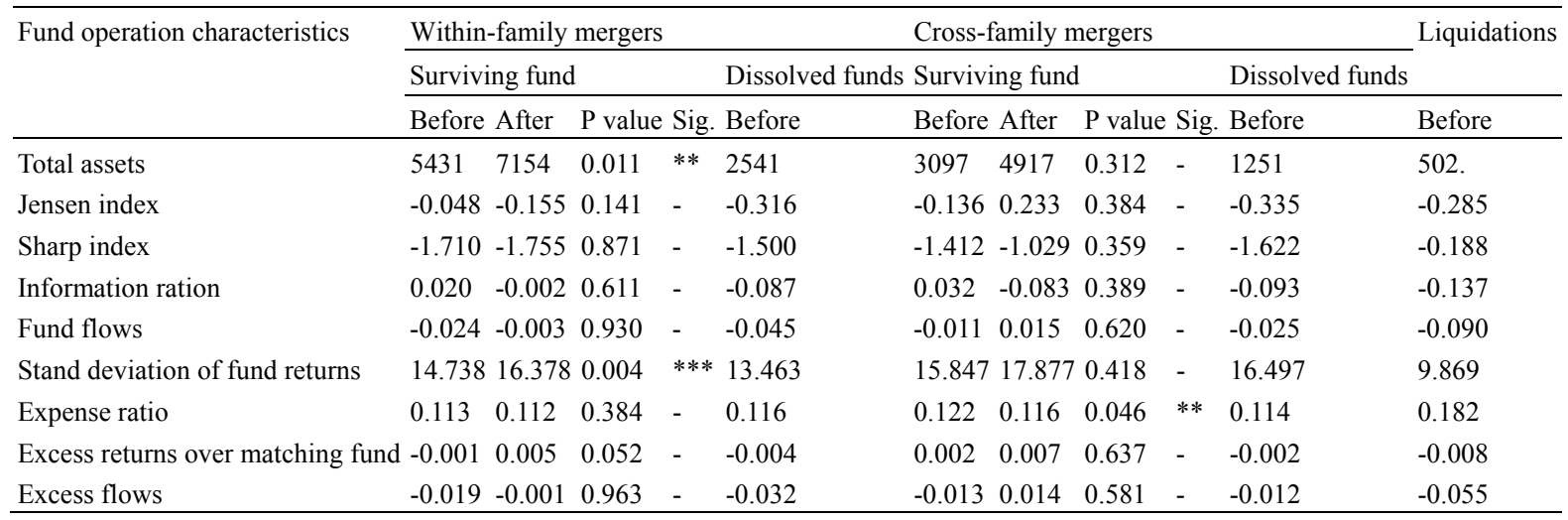

Description: We examined the changes in liquidated funds and the surviving funds and dissolved funds that underwent within-family or cross-family mergers during the year before and the year following liquidations or mergers. We adopted the formula proposed by Sirri and Tufano (1998) to define fund flow, that is, $\left[T N A_{t}-\left(1+r_{t}\right) T N A_{t-1}\right] / T N A_{t-1}$. Expense ratio $=[($ manager fees + custodial fees + guarantee fees + other fees) / 1000] / fund net asset (thousands of NT dollars) X 100\%. The performance indices comprised the original rate of return, Jensen's $\alpha$, Sharpe index, and information ratio. Abnormal flow was obtained based on calculations of the matching funds that had similar investment objectives or targets. The corresponding matching funds are all of the same investment object funds. ${ }^{* * *}$ indicates that the $\alpha$ reached a level of significance at $1 \%$; ** indicates that the $\alpha$ reached a level of significance at 5\%. Significant (Sig.).

\subsection{The Robustness Test}

According to Table I, which includes the statistics of the fund liquidations and mergers, the number of fund liquidations did not exceed 10 until 2005, which was the beginning of a wave of fund liquidations and mergers. Considering that samples before 2005 are rare and that the causes of early fund liquidations might differ from 
those of recent liquidations, we excluded early samples and retested the statistics. We again employed cross-sectional and time-series regression in the robustness test.

The results of the cross-sectional multinomial logit regression analysis of the within-family and cross-family mergers showed that when the statistics reached a significance level of 0.05 , the results did not differ significantly from those that included samples from 2005. Despite a slight difference in the statistical significance results obtained through the multinomial logit regression coefficient test for within-family mergers and although low performance volatility became significant, the remaining variables were identical to the results obtained before the robust test. Therefore, we conclude that in addition to small total assets, low short-term fund flows, and poor previous performance, another characteristic of Taiwanese within-family mergers following 2006 is low performance volatility. Among the factors that affect cross-family mergers, none of the variables changed significantly except for the long-term (that is, 24 months) performance in Model 2, which became insignificant. The characteristics of the liquidated funds did not change, with one exception. In Model 1, the regression coefficient of Jensen's $\alpha$ in the previous month changed to a statistically significant negative correlation. The results of the time-series logistic regression of the cross-family mergers and liquidations did not differ significantly from those obtained without excluding samples from 2005. This does not change the conclusion that variations in particular fund characteristics can cause fund companies to merge or liquidate certain funds rapidly.

\section{Conclusion and Discussion}

The present study explored the relationship between fund flows and fund exit strategies of Taiwanese funds. We employed multinomial and time-series logit regression analysis for the empirical analysis to (1) identify the operating characteristics that cause fund companies to liquidate or merge certain funds and (2) test whether fund companies can achieve the promises and benefits they describe when they announce mergers.

The empirical results and analysis conclusions of this study are as follows. First, in general, fund companies claimed that because fund scales were excessively small, they were unable to pay for the funds' fixed expenses. This inability would affect the quality of fund operations and jeopardize the clients' rights and interests. Therefore, fund companies opted for fund mergers. However, although expense ratios declined following mergers and fund flows increased, the quality of the funds' operational performance was not necessarily enhanced. Investors should therefore consider carefully and rationally whether they want to continue investing in surviving funds. Fund performance varied depending on various performance measurement indices, and operational performance did not necessarily improve. This indicates that although fund companies expect to use mergers to reduce administrative costs and return a reasonable sum of costs to investors, they do not necessarily achieve these goals in subsequent performance.

Second, among various fund exit strategies, the market prefers that fund companies perform mergers rather than liquidations when fund scales are small. This is the case because mergers can significantly reduce the stock selling pressure that results from fund liquidations. Notably, fund liquidations outnumbered mergers during the decade between 2001 and 2010. Fund companies should enhance the quality of their operations during early fund raising or the subsequent management processes to prevent their funds from being closed. Otherwise, fund companies do not have to pay for their mistakes, and investors must continually suffer losses.

Third, before conducting within-family mergers, fund companies should examine the performance records of the surviving and the dissolved funds. Fund companies tend to eliminate funds that have poor previous records, small total assets, and low flows. Fund flows increased and operating costs decreased one year following the merger. Although the expense ratios declined, the shareholders of the dissolved and surviving funds did not gain higher returns from the mergers. When surviving funds in within-family mergers have lower mean flows during the six months preceding a merger compared to other points in the lifecycle, the fund companies tend to merge funds with other funds within the same families. Similarly, when the dissolved funds in within-family mergers have lower mean flows during the six months preceding a merger compared to those at other points in the lifecycle, fund companies tend to merge (eliminate) these funds.

Fourth, fund flows increased and operating costs decreased one year following cross-family mergers. For the shareholders of the dissolved funds, however, although the expense ratios increased, this did not determine fund exits. In contrast, total assets, previous flows, and previous performance are crucial factors for fund exits. For the shareholders of the surviving funds, although expense ratios declined, the potential quality of the returns following mergers was uncertain and volatility levels were significant. However, these factors do not determine fund exits. In general, the considerations for fund exits were strategic rather than based on specific factors.

Fifth, Brown and Goetzmann (1995), Horst et al. (2001), and Zhao (2005) found that newly established funds 
were more likely to be liquidated, whereas Lunde et al. (1999) argued that young or extremely old funds were likely to be closed. However, the fund's age was not a factor among Taiwanese fund exit strategies. When fund companies liquidate funds that have been established for a relatively long period simply because of small fund scales, fund investors who engage in long-term investments (Barber et al., 2005) are forced to sell their funds during stock market lows. Clearly, this is against the "buy low, sell high" investment philosophy. We recommend, therefore, that Taiwanese domestic long-term investors pay increased attention to fund scale, performance volatility, long-term performance, fund flow, and whether the mean flow of a fund during the six months prior to a certain point in its lifecycle is low compared with these factors at other points of the fund's lifecycle. Investors should base investment decisions on these factors to avoid being forced to terminate their investments at any particular point. By so doing, they can avoid incurring long-term investment losses and the negative consequences that result from fund termination or mergers.

Sixth, during within-family and cross-family mergers, the total assets of the surviving funds increased, which was consistent with the increases in flows, whereas expense ratios declined (Kumar and Bansal, 2008). In within-family mergers, the mean flows during the prior six months were lower compared to those at other points of the lifecycle. Therefore, such funds were likely to merge with or acquire other funds. In cross-family mergers, we did not identify any fund characteristic-related lifecycle characteristics that contributed to fund exits. Seventh, funds that had small total assets, low previous flows, and poor long-term performance were likely to be eliminated. Furthermore, the mean flow during the prior six months and poor long-term (that is, 24 months) performance compared to those of other outside-family funds are factors that determine within-family mergers. In contrast, we did not find any fund characteristic-related lifecycle characteristics that affected cross-family mergers.

The majority of the investors tend to purchase funds that have superior recent performance (Sirri and Tufano, 1998), and they tend to believe that funds that fund companies rename and beautify yield extraordinary returns. Indeed, the opposite is true (Cooper et al., 2005). In addition, we found that the investing public tends to be relatively passive. When fund companies perform simple and appropriate mergers, public investors of the dissolved fund and the surviving fund can be convinced easily that the merger will yield superior performance or that the funds can be transformed into funds that have more popular investment targets. In general, however, although fund flows increase following mergers, performance is not necessarily improved, indicating that Taiwanese investors' misjudgments or inappropriate behavior (Chen et al., 2011) are influenced potentially by trusting fund companies' claims that liquidations and mergers will yield expected benefits. In fact, fund managers may benefit from mergers because investors tend to focus on the proclaimed benefits of liquidations or mergers while neglecting original poor performance. This is consistent with conclusions from previous studies that have asserted that the majority of investors use scant professional knowledge in selecting products for purchase (Capon et al., 1996). Because investors tend to follow trends rather than make rational judgments based on previous fund performance, they can arrive at erroneous or biased investment decision behavior (Bailey et al., 2011).

\section{References}

Agrawal, A., Jaffe, J. F., \& Mandelker, G. N. (1992). The Post-merger Performance of Acquiring Firms: A Re-examination of an Anomaly. Journal of Finance, 47, 1605-1621. http://dx.doi.org/10.1111/j.1540-6261.1992.tb04674.x

Agresti, A. (1996). An Introduction to Categorical Data Analysis. New York: John Wiley \& Sons.

Ahmad, Y., \& Kashian, R. (2010). Modeling the Time to an Initial Public Offering: When Does the Fruit Ripen? Journal of Economics and Finance, 34(4), 391-414. http://dx.doi.org/10.1007/s12197-008-9073-z

Allen, D. E., \& Parwada, J. T. (2006). Investors' Response to Mutual Fund Company Mergers. International Journal of Managerial Finance, 2(2), 21-35. http://dx.doi.org/10.1108/17439130610657340

Bailey, W., Kumar, A., \& Ng, D. (2011). Behavioral Biases of Mutual Fund Investors. Journal of Financial Economics, 102(1), 1-27. http://dx.doi.org/10.1016/j.jfineco.2011.05.002

Barber, B. M., Odean, T., \& Zheng, L. (2005). Out of Sight, Out of Mind: the Effects of Expenses on Mutual Fund Flows. Journal of Business, 78, 2095-2119. http://dx.doi.org/10.1086/497042

Barksdale, H. C., \& Harris, C. E. (1982). Portfolio Analysis and the Product Life Cycle. Long Range Planning, 15(6), 74-83. http://dx.doi.org/10.1016/0024-6301(82)90010-3

Bekaert, G., \& Harvey, C. R. (2002). Emerging Market Finance. National Bureau of Economic Research, Cambridge, MA, USA. 
Berk, J. B., \& Green, R. C. (2004). Mutual Fund Flows and Performance in Rational Markets. Journal of Political Economy, 112, 1269-1295. http://dx.doi.org/10.1086/424739

Bris, A., Gulen, H., Kadiyala, P., \& Rau, P. R. (2007). Good Stewards, Cheap Talkers, or Family Men? The Impact of Mutual Fund Closures on Fund Managers. Review of Financial Studies, 20(3), 953-982. http://dx.doi.org/10.1093/rfs/hhl017

Brown, S. J., \& Goetzmann, W. N. (1995). Performance Persistence. Journal of Finance, 50, 679-698. http://dx.doi.org/10.1111/j.1540-6261.1995.tb04800.x

Brown, S. J., Goetzmann, R. G., \& Ross, S. A. (1992). Survivorship Bias in Performance Studies. The Review of Financial Studies, 5(4), 553-580. http://dx.doi.org/10.1093/rfs/5.4.553

Bu, Q., \& Lacey, N. (2009). On Understanding Mutual Fund Terminations. Journal of Economics and Finance, 33(1), 80-99. http://dx.doi.org/10.1007/s12197-007-9022-2

Cakici, N., \& Chatterjee, S. (2007). Hedge Fund Mergers. Journal of Investment Management, 5(2), 99-111.

Cameron, A. C., \& Hall, A. D. (2003). A Survival Analysis of Australian Equity Mutual Funds. Australian Journal of Management, 28(2), 209-226.

Capon, N., Fitzsimmons, G. J., \& Prince, R. A. (1996). An Individual Level Analysis of the Mutual Fund Investment Decision. Journal of Financial Services Research, 10, 59-82. http://dx.doi.org/10.1007/BF00120146

Chen, A. H. L., Cheng, K., \& Lee, Z. H. (2011). The Behavior of Taiwanese Investors in Asset Allocation. Asia Pacific Journal of Business Administration, 3(1), 62-74. http://dx.doi.org/10.1108/17574321111116405

Cooper, M. J. K., Gulen, H., \& Rau, P. R. (2005). Changing Names with Style: Mutual Fund Name Changes and Their Effects on Fund Flows. Journal of Finance, 60, 2825-2858. http://dx.doi.org/10.1111/j.1540-6261.2005.00818.x

Cox, D. R. (1970). The Analysis of Binary Data. London: Chapman and Hall.

Dritsakis, N., Grose, C., \& Kalyvas, L. (2006). Performance Aspects of Greek Bond Mutual Funds. International Review of Financial Analysis, 15(2), 189-199. http://dx.doi.org/10.1016/j.irfa.2005.10.001

Elton, E. J., Gruber, M. J., \& Blake, C. (1996). Survivorship Bias and Mutual Fund Performance. Review of Financial Studies, 9, 1097-1120. http://dx.doi.org/10.1093/rfs/9.4.1097

Evans, R. B. (2004). Does Alpha Really Matter? Evidence from Mutual Fund Incubation, Termination and Manager Change, University of Pennsylvania, Working Paper.

Gruber, M. J. (1996). Another Puzzle: The Growth in Actively Managed Mutual Funds. The Journal of Finance, 51(3), 783-810. http://dx.doi.org/10.1111/j.1540-6261.1996.tb02707.x

Hausman, J., \& McFadden, D. (1984). Specication Tests for the Multinomial Logit Model. Econometrica, 52(5), 1219-1240. http://dx.doi.org/10.2307/1910997

Horst, J., Nijman, T., \& Verbeek, M. (2001). Eliminating Look-ahead Bias in Evaluating Persistence in Mutual Fund Performance. Journal of Empirical Finance, 8(4), 345-373. http://dx.doi.org/10.1016/S0927-5398(01)00032-9

Huang, J. C., Wei, K. D., \& Yan, H. (2012). Investor Learning and Mutual Fund Flows. AFA 2012 Chicago Meetings Paper.

Huang, J., Wei, K. D., \& Yan, H. (2007). Participation Costs and the Sensitivity of Fund Flows to Past Performance. Journal of Finance, 62(3), 1273-1311. http://dx.doi.org/10.1111/j.1540-6261.2007.01236.x

Jayaraman, N., Khorana, A., \& Nelling, E. (2002). An analysis of the Determinants and Shareholder Wealth Effects of Mutual Fund Mergers. The Journal of Finance, 57(3), 1521-1552. http://dx.doi.org/10.1111/1540-6261.00468

Johnsen, T., \& Melicher, R. (1994). Predicting Corporate Bankruptcy and Financial Distress: Information Value added by Multinomial Logit Models. Journal of Econimics and Business, 46, 269-286. http://dx.doi.org/10.1016/0148-6195(94)90038-8

Kempf, A., \& Ruenzi, S. (2008). Tournaments in mutual fund families. Review of Financial Studies, 21, 1013-1036. http://dx.doi.org/10.1093/rfs/hhm057

Khorana, A., Tufano, P., \& Wedge, L. (2007). Board Structure, Mergers and Shareholder Wealth: A Study of the 
Mutual Fund Industry. Journal of Financial Economics, 85(2), 571-598. http://dx.doi.org/10.1016/j.jfineco.2006.05.002

Kumar, S., \& Bansal, L. K. (2008). The Impact of Mergers and Acquisitions on Corporate Performance in India. Management Decision, 46(10), 1531-1543. http://dx.doi.org/10.1108/00251740810920029

Lunde, A., Timmerman, A., \& Blake, D. (1999). The Hazards of Mutual Fund Underperformance: A Cox Regression Analysis. Journal of Empirical Finance, 6, 121-152. http://dx.doi.org/10.1016/S0927-5398(98)00013-9

Massa, M., \& Patgiri, R. (2009). Incentives and Mutual Fund Performance: Higher Performance or Just Higher Risk Taking? The Review of Financial Studies, 22(5), 1777-1815. http://dx.doi.org/10.1093/rfs/hhn023

McFadden, D. (1973). Conditional Logit Analysis of Qualitative Choice Behavior. In P. Zarembka (Ed.), Strutural Analysis of Discrete Data with Econometric Application (pp. 105-135). Combridge: MIT Press.

Muga, L., \& Santamaria, R. (2010). Market Penetration Strategies and the Fee-performance Relationship: the Case of Spanish Money Mutual Funds. The Service Industries Journal, 30(9), 1529-1547. http://dx.doi.org/10.1080/02642060802626816

Namvar, E., \& Phillips, B. (2013). Commonalities in Investment Strategy and The Determinants of Performance in Mutual Fund Mergers. Journal of Banking \& Finance, 37(2), 625-635. http://dx.doi.org/10.1016/j.jbankfin.2012.10.001

Ping, H. (2001). Two Essays on Mutual Fund Risk-Taking and Flow-Performance Relationship, Georgia State University.

Sirri, E. R., \& Tufano, P. (1998). Costly Search and Mutual Fund Flows. Journal of Finance, 53(5), $1589-1622$. http://dx.doi.org/10.1111/0022-1082.00066

Vayanos, D. (2004). Flight to Quality, Flight to Liquidity, and the Pricing of Risk. NBER Working Paper.

Wang, N. Y., \& Chen, B. H. (2009). A Study of Survivorship Bias, Fund Categories and Fund Performance Persistence. Journal of Management, 26(6), 673-696.

Zhao, X. (2005). Exit Decisions in the U.S. Mutual Fund Industry. The Journal of Business, 78(4), $1365-1392$. http://dx.doi.org/10.1086/430863

Zhou, X., \& Chiang, K. C. H. (2007). Mutual Fund Postacquisition Management Retention and Its Performance Implications. Corporate Finance Review, 11(6), 28-34. 